\title{
Infeksi Saluran Kemih Sebagai Faktor Risiko Terjadinya Ancaman Persalinan Preterm
}

\author{
Henky Mohammad Masteryanto', Gatut Hardianto', Hermanto Tri Joewono', Eko Budi Koendhori' \\ 'Departemen Obstetri dan Ginekologi, ${ }^{2}$ Departemen Mikrobiologi Klinik \\ Fakultas Kedokteran Universitas Airlangga, RSUD Dr Soetomo, Surabaya
}

\section{ABSTRAK}

Tujuan: Mengidentifikasi kuman penyebab infeksi saluran kemih sebagai faktor risiko terjadinya ancaman persalinan preterm.

Bahan dan Metode: Penelitian ini adalah penelitian analitik observasional cross sectional, dilakukan di Kamar Bersalin dan Poli Hamil RSUD Dr. Soetomo serta di Bagian Mikrobiologi Kedokteran Fakultas Kedokteran Universitas Airlangga Surabaya, pada bulan Januari-April 2015. Penghitungan jumlah koloni dan identifikasi kuman dilakukan melalui pemeriksaan kultur urine porsi tengah dan dilanjutkan dengan tes kepekaan antibiotika. Analisa statistik menggunakan uji Chi square untuk jumlah koloni kuman dan bakteriuria, dan uji Fischer exact untuk jenis kuman, menggunakan perangkat lunak SPSS 20. 0 .

Hasil: Sampel terdiri dari 20 wanita hamil dengan ancaman persalinan preterm/partus prematurus iminens (PPI) dan 20 wanita hamil normal tunggal dengan usia kehamilan 28-36 minggu. Perbandingan antara jumlah koloni kuman kedua kelompok secara statistik tidak signifikan, dengan nilai $\mathrm{p}=0,063(\mathrm{p}>0,05)$, perbedaan jenis kuman yang ditemukan antara kedua kelompok secara statistik tidak signifikan, dengan nilai $\mathrm{p}=0,058(\mathrm{p}>0,05)$.

Simpulan: Pada kehamilan dengan ancaman persalinan preterm $80 \%$ didapatkan pertumbuhan kuman Staphylococcus epidermidis (30\%) dan Escherichia coli (15\%). Jumlah koloni kuman aerob urine pada kehamilan dengan ancaman persalinan preterm lebih banyak dibandingkan dengan kehamilan tanpa ancaman persalinan preterm, tetapi secara statistik tidak berbeda bermakna. Risiko terjadinya PPI pada wanita hamil dengan jumlah koloni kuman urine $>10^{5}$ cfu/mL 3 kali lebih besar dibanding wanita hamil dengan jumlah koloni $<10^{5} \mathrm{cfu} / \mathrm{mL}$. Jenis kuman aeroburine pada kehamilan dengan dan tanpa ancaman persalinan preterm hampir sama.

Kata kunci: pola kuman aerob urine, kehamilan dengan ancaman persalinan preterm, infeksi saluran kemih

\begin{abstract}
Objectives: To identify bacteria causing urinary tract infection as a risk factor of preterm delivery.

Materials and Methods: the design of this study was observational analytics, cross sectional, at delivery room and obstetric outpatient clinic Dr. Soetomo Hospital, Surabaya and Medical Microbiology department, Airlangga University, Surabaya, Indonesia, inJanuary-April 2015. Bacterial colony count and identification performed by midstream urine culture, followed by antibiotics sensitivity tests. Chi square and Fischer exact test used for statistical analysis of bacterial colony count and bacterial identification.

Results: Samples consists of 20 pregnant women with preterm threatened labor and 20 normal pregnant women, singleton, 28-36 weeks of gestational age. Comparison between bacterial colony count and identification was statistically not significant. But the risk of preterm threatened labor on UTI women was three times greater than non-UTI.

Conclusion: $80 \%$ subject of preterm threatened labor was found bacterial growth Staphylococcus epidermidis $(30 \%)$ and Escherichia coli $(15 \%)$. Urinal aerobic bacterial colony at pregnancy with preterm threatened labor was larger than normal pregnancy, but statistically not significant. Risk of preterm threatened labor in women with colony $>10^{5} \mathrm{cfu} / \mathrm{mL} 3$ fold greater than colony $<10^{5} \mathrm{cfu} / \mathrm{mL}$. Species of aerobic bacteria between two groups was almost similar.
\end{abstract}

Keywords: Urinal aerobic bacterial pattern, pregnancy with threatened preterm labor, urinary tract infection

Correspondence: Henky Mohammad Masteryanto, Departemen Obstetri dan Ginekologi, Fakultas Kedokteran Universitas Airlangga, RSUD dr. Soetomo, Surabaya, Jawa Timur, Indonesia, telp. +6281334425804, email: henky. mm@gmail. com

\section{PENDAHULUAN}

Persalinan preterm menurut WHO didefinisikan sebagai persalinan yang terjadi pada usia kehamilan $<37$ minggu. Persalinan preterm ini merupakan salah satu penyumbang dari mortalitas dan morbiditas jangka pendek maupun jangka panjang pada bayi baru lahir. Di Amerika Serikat kejadian persalinan preterm sebesar 12,5\% dalam setahun, dan di Eropa bervariasi antara 5\% sampai 7\% dari total persalinan. ${ }^{1,2}$ Di Indonesia, angka kejadian persalinan preterm pada tahun 1983 sebesar $18,5 \%$, tahun 1995 sebesar 14,2\%, dan pada tahun 2005 dilaporkan sebesar $10 \%{ }^{3}$ Dalam RISKESDAS tahun 2013 prosentase bayi lahir berat $<2500$ gram sebesar
10,2\%. ${ }^{4}$ Data Fetomaternal RSUD Dr. Soetomo tahun 2014, dilaporkan kejadian persalinan preterm sebesar $18,84 \%$ dari seluruh persalinan. Dan $46 \%$ merupakan persalinan dengan indikasi obstetri, 24\% adalah persalinan spontan, sisanya akibat dari ketuban pecah dini, dengan persentase kematian perinatal mencapai $80,1 \%$.

Prematuritas masih sebagai penyumbang terbesar kematian bayi baru lahir di beberapa negara berkembang, di sebuah jurnal disebutkan angka mortalitas pada bayi preterm sebesar $75-80 \%$, dan sekitar $40 \%$ dari kematian tersebut terjadi pada usia kehamilan $<32$ minggu. ${ }^{2}$ Dari segi ekonomi, prematuritas juga merupa- 
kan salah satu faktor yang menyebabkan tingginya biaya perawatan bayi baru lahir, mencakup penggunaan ventilator mekanik, pemberian obat-obatan, dan waktu perawatan yang lama. ${ }^{5,6}$

Banyak faktor yang disebut sebagai faktor risiko terjadinya persalinan preterm, antara lain infeksi, inflamasi, perdarahan, regangan dinding uterus yang berlebih (misalnya kehamilan multipel, hidramnion), trauma, stress, proses imunologis dan inkompetensi serviks. Infeksi intrauterin merupakan salah satu faktor yang cukup penting dan sering yang berkaitan dengan terjadinya persalinan preterm, mekanisme dari infeksi ini melalui sistem imunitas tubuh ibu terhadap mikroorganisme. ${ }^{1}$

Sekitar 39,6\% dari persalinan preterm diduga disebabkan oleh karena infeksi. Salah satu infeksi yang cukup banyak terjadi pada kehamilan adalah infeksi saluran kemih. Disebutkan karena perubahan anatomi dan fungsional dari kehamilan dapat meningkatkan risiko infeksi saluran kemih, sekitar 2 sampai $7 \%$ wanita hamil didapatkan bakteriuria asimptomatik, bakteri yang ditemukan sebagian besar adalah Escherichia coli. Sebuah studi meta-analisa tahun 1989, Romero menyebutkan bahwa wanita dengan bakteriuria asimptomatik memiliki risiko terjadinya persalinan preterm lebih besar dibanding wanita tanpa bakteriuria. ${ }^{7}$

Wanita hamil dengan bakteriuria asimptomatik bila tidak diterapi dengan tepat $25 \%$ dapat berkembang menjadi bakteriuria yang simptomatik atau disebut dengan infeksi saluran kemih. ${ }^{8}$ Goldenberg (2008) menyebutkan bahwa infeksi intrauterine dapat menyebabkan $25-40 \%$ persalinan preterm. Sebuah studi di Mesir menyebutkan bahwa wanita hamil dengan infeksi saluran kemih mempunyai risiko cukup besar terjadinya persalinan preterm $($ Odd ratio $=1,8) .{ }^{9}$ Penata-laksanaan wanita hamil dengan bakteriuria asimpto-matik dan infeksi saluran kemih yang sesuai dapat menurunkan risiko persalinan preterm serta dapat mencegah komplikasi lebih lanjut pada ibu (misalnya pyelonefritis, cystitis). ${ }^{7}$

\section{BAHAN DAN METODE}

Penelitian ini adalah penelitian analitik observasional cross sectional, dilaksanakan di Kamar Bersalin dan Poli Hamil RSUD Dr. Soetomo serta di Bagian Mikrobiologi Kedokteran Fakultas Kedokteran Universitas Airlangga Surabaya, pada bulan JanuariApril 2015. Populasi pasien di Kamar Bersalin dan Poli Hamil RSUD Dr. Soetomo Surabaya, dibagi menjadi 2 kelompok, yaitu kehamilan tanpa ancaman persalinan preterm dan kehamilan dengan ancaman persalinan preterm. Penghitungan jumlah koloni dan identifikasi kuman dilakukan melalui pemeriksaan kultur urine porsi tengah dan dilanjutkan dengan tes kepekaan antibiotika. Dengan menggunakan nilai $\mathrm{p}=0,05$ dan tingkat kemaknaan $80 \%$, didapatkan besar sampel 20 untuk masing-masing kelompok. Pengambilan sampel dilakukan secara consecutive sampling.

Pada penelitian ini menggunakan kriteria Inklusi: Kelompok kontrol: Pasien dengan kehamilan normal, usia 28-36 minggu, kelompok kasus: Pasien hamil dengan ancaman persalinan preterm, usia 28-36 minggu, kehamilan tunggal, selaput ketuban utuh. Kriteria eksklusi: Pasien dengan kelainan medik yang sistemik, seperti diabetes mellitus, hipertensi dalam kehamilan, penyakit autoimun, dan lain-lain, pasien yang mengkonsumsi antibiotik dalam 1 minggu sebelum MRS, pasien dengan kelainan obstetri: janin dengan kelainan kongenital mayor, polihidramnion, riwayat insufisiensi serviks, pasien menderita fluor albus, dan pasien tidak bersedia mengikuti penelitian.

Analisa data menggunakan uji Chi square untuk jumlah koloni kuman dan bakteriuria, dan uji Fischer exact untuk jenis kuman, menggunakan perangkat lunak SPSS 20. 0. Penelitian ini telah mendapatkan surat persetujuan/kelaikan etik dari komisi etik untuk penelitian dasar/klinik di RSUD Dr. Soetomo/Fakultas Kedokteran Universitas Airlangga, Surabaya.

\section{HASIL DAN PEMBAHASAN}

Pada penelitian ini kami mengumpulkan total 40 subyek penelitian yang kami bagi menjadi 2 kelompok, yaitu kelompok kehamilan dengan ancaman persalinan preterm/partus prematurus iminens (PPI) dan kelompok kehamilan tanpa ancaman persalinan preterm/kontrol.

Kuman aerob dipilih pada penelitian ini karena dalam beberapa studi terdahulu penyebab ISK terbesar adalah kuman aerob, baik pada wanita hamil maupun tidak hamil. Selain itu ISK yang disebabkan oleh kuman anaerob sangat jarang terjadi, dan secara klinis dikatakan bahwa tidak didapatkan relevansi antara kuman anaerob pada pasien dengan ISK. Kultur urine untuk kuman anaerob bukan merupakan prosedur rutin pada kasus dengan kecurigaan ISK, pemeriksaan kultur kuman anaerob hanya dilakukan pada pasien dengan abnormalitas anatomi, misalnya pada kasus fistula enterovesika, dimana resiko terjadinya ISK oleh kuman anaerob yang berasal dari saluran pencernaan sangat besar dan pada kasus pyuria. ${ }^{27}$

Dari data penelitian kami dapatkan usia rata-rata kelompok PPI adalah 27,35 \pm 5,62 tahun, dengan usia 
paling muda 20 tahun dan paling tua 39 tahun, pada kelompok kontrol adalah 28,25 \pm 4,98 tahun dengan usia paling muda 20 tahun dan paling tua 42 tahun. Dari kedua kelompok tersebut didapatkan nilai $\mathrm{p}$ sebesar 1,000 , dari nilai $\mathrm{p}$ tersebut disimpulkan bahwa antara usia terhadap kejadian PPI tidak berbeda bermakna. Hal serupa dikemukakan oleh Nabavizadeh dkk (2012), dalam penelitiannya usia ibu tidak berbeda bermakna antara kelompok kasus preterm dengan kontrol, didapatkan nilai $p$ sebesar $0,21 .{ }^{10}$

Demikian juga pada penelitian Begum, dkk (2003) usia ibu tidak signifikan terhadap terjadinya PPI, dalam penelitian tersebut didapatkan nilai $\mathrm{p}=0,228$. Penelitian Dekker dkk (2012) menyatakan usia ibu tidak bermakna terhadap kejadian PPI, dengan nilai $\mathrm{p}=0,900 .{ }^{12}$ Tetapi pada penelitian Grillo, dkk menyatakan bahwa usia ibu pada saat persalinan $\leq 19$ tahun memiliki angka yang bermakna secara statistik dengan nilai $p=0,030(p<0,05)$

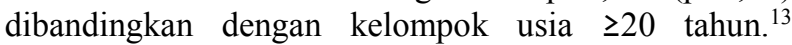
Kozuki dkk (2013) dalam studinya mengenai usia ibu dengan risiko terjadinya persalinan preterm menyebutkan bahwa ibu dengan usia $<18$ tahun memiliki risiko sangat tinggi melahirkan bayi preterm, dalam penelitiannya didapatkan odd ratio sebesar 3,14 (CI $95 \% ; 2,18-4,53) .{ }^{14}$

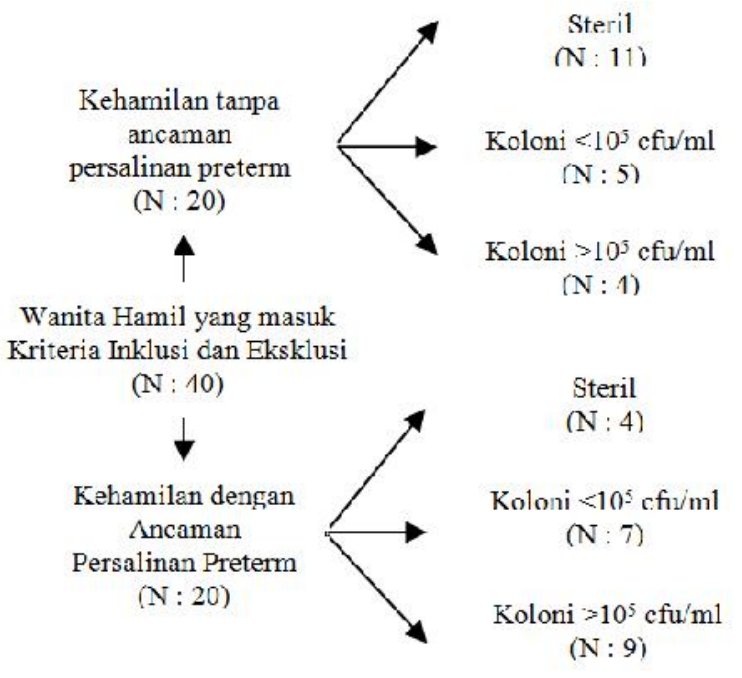

Gambar 1. Diagram alur penelitian

Pada penelitian yang kami lakukan tidak didapatkan hasil yang signifikan karena usia subyek termuda dari kedua kelompok adalah 20 tahun. Pada penelitian yang menyebutkan bahwa kehamilan pada usia muda dapat meningkatkan risiko terhadap terjadinya persalinan preterm, mekanisme secara pasti belum dapat dipastikan, salah satu mekanisme yang diduga adalah karena fungsi fisiologis dari tubuh wanita usia muda masih belum matang, baik secara hormonal maupun anatomi. ${ }^{13,14}$ Status gizi berdasarkan indeks massa tubuh rata-rata kelompok PPI 25,89 $\pm 5,39 \mathrm{~kg} / \mathrm{m} 2$, pada kelompok kontrol adalah $26,78 \pm 6,38 \mathrm{~kg} / \mathrm{m} 2$. Dari kedua kelompok tersebut didapatkan nilai $\mathrm{p}$ sebesar 0,495, dari nilai $\mathrm{p}$ tersebut disimpulkan bahwa antara status gizi terhadap kejadian PPI tidak berbeda bermakna. Seperti halnya Dekker, dkk (2012), dalam penelitiannya disebutkan bahwa status gizi tidak memiliki perbedaan yang signifikan terhadap terjadinya persalinan preterm, dalam penelitiannya didapatkan nilai $p$ sebesar $0,58 .{ }^{11}$.

Tabel 1. Karakteristik subyek penelitian

\begin{tabular}{|c|c|c|c|}
\hline Variabel & $\begin{array}{c}\text { PPI } \\
\mathrm{N}=20(\%)\end{array}$ & $\begin{array}{c}\text { Kontrol } \\
\mathrm{N}=20(\%)\end{array}$ & $p^{*}$ \\
\hline \multicolumn{4}{|l|}{ Paritas } \\
\hline Primigravida & $6(30,0)$ & $10(50,0)$ & \multirow[t]{2}{*}{0,333} \\
\hline Multigravida & $14(70,0)$ & $10(50,0)$ & \\
\hline \multicolumn{4}{|l|}{ Pendidikan } \\
\hline SD & $2(10,0)$ & $0(0,0)$ & \multirow[t]{4}{*}{0,022} \\
\hline SMP & $5(25,0)$ & $1(5,0)$ & \\
\hline SMA & $12(60,0)$ & $13(65,0)$ & \\
\hline PT & $1(5,0)$ & $6(30,0)$ & \\
\hline \multicolumn{4}{|l|}{ Usia (tahun) } \\
\hline$<18$ & $0(0,0)$ & $0(0,0)$ & \multirow[t]{4}{*}{1,000} \\
\hline $18-35$ & $18(90,0)$ & $18(90,0)$ & \\
\hline$>35$ & $2(10,0)$ & $2(10,0)$ & \\
\hline Rerata & $27,35 \pm 5,62$ & $28,25 \pm 4,98$ & \\
\hline \multicolumn{4}{|l|}{$\begin{array}{l}\text { Usia Kehamilan } \\
\text { (minggu) }\end{array}$} \\
\hline $28-32$ & $10(50,0)$ & $9(45,0)$ & \multirow[t]{3}{*}{0,755} \\
\hline $32-36$ & $10(50,0)$ & $11(55,0)$ & \\
\hline Rerata & $32,43 \pm 2,02$ & $32,26 \pm 2,89$ & \\
\hline \multicolumn{4}{|l|}{ Status Gizi } \\
\hline Underweight & $1(5,0)$ & $0(0,0)$ & \multirow[t]{6}{*}{0,495} \\
\hline Normal & $7(35,0)$ & $9(45,0)$ & \\
\hline Overweight & $10(50,0)$ & $6(30,0)$ & \\
\hline Obesitas gr. I & $1(5,0)$ & $3(15,0)$ & \\
\hline Obesitas gr. II & $0(0,0)$ & $0(0,0)$ & \\
\hline Obesitas gr. III & $1(5,0)$ & $2(10,0)$ & \\
\hline \multicolumn{4}{|c|}{ Frekuensi Hubungan } \\
\hline \multicolumn{4}{|c|}{ Seksual } \\
\hline 1x/mgg & $8(40,0)$ & $5(25,0)$ & \multirow[t]{4}{*}{0,110} \\
\hline $1-2 x / m g g$ & $2(10,0)$ & $3(15,0)$ & \\
\hline $1 \mathrm{x} / \mathrm{b} \ln$ & $10(50,0)$ & $7(35,0)$ & \\
\hline $1-2 x / b \ln$ & $0(0,0)$ & $5(25,0)$ & \\
\hline \multicolumn{4}{|l|}{ Hubungan Seksual } \\
\hline \multicolumn{4}{|l|}{ Terakhir } \\
\hline$<1 \mathrm{mgg}$ & $14(70,0)$ & $10(50,0)$ & \multirow[t]{4}{*}{0,088} \\
\hline $1-2 \mathrm{mgg}$ & $0(0,0)$ & $5(25,0)$ & \\
\hline $2-4 \mathrm{mgg}$ & $1(5,0)$ & $2(10,0)$ & \\
\hline$>1$ bln & $5(25,0)$ & $3(15,0)$ & \\
\hline
\end{tabular}

Sedangkan pada penelitian Grillo dan Begum menyatakan bahwa status gizi mempunyai nilai yang bermakna terhadap terjadinya persalinan preterm, dalam penelitiannya indeks massa tubuh $? 19 \mathrm{~kg} / \mathrm{m} 2$ memiliki risiko meningkatnya persalinan preterm. ${ }^{12,13}$. Dalam penelitian Grillo dkk (2011) diperoleh OR : 1,40;95\% CI, 0,92-2,13 dan $\mathrm{p}=0,04$. Begum, dkk (2003) dalam penelitiannya didapatkan OR : 2,91; 95\% CI, 1,69-5,02 dan nilai $\mathrm{p}<0,001 .^{12,13}$ Pada penelitian ini tidak didapatkan hasil yang signifikan karena hanya 1 subyek kehamilan dengan ancaman persalinan preterm dengan status gizi kurang/underweight (IMT $<19 \mathrm{~kg} / \mathrm{m} 2$ ). 
Status gizi kurang (IMT $<20 \mathrm{~kg} / \mathrm{m} 2$ ) terutama sebelum kehamilan merupakan suatu penanda bahwa lingkungan untuk kehamilannya tidak baik untuk janin, dan dapat diduga sebagai suatu faktor langsung terhadap terjadinya persalinan preterm.

Frekuensi hubungan seksual dan jarak hubungan seksual terakhir pada kedua kelompok tidak didapatkan perbedaan yang signifikan, dengan nilai p masing-masing adalah 0,110 dan 0,88 . Tingkat pendidikan dalam penelitian ini didapatkan perbedaan yang bermakna pada kedua kelompok, dengan nilai $\mathrm{p}=0,022(\mathrm{p}<0,05)$. Dalam penelitian Begum, dkk (2003) menyebutkan bahwa pendidikan rendah $(<5$ tahun $)$ memiliki nilai yang signifikan terhadap terjadinya risiko persalinan preterm, dalam penelitiannya didapatkan nilai $\mathrm{p}<0,05 .{ }^{12}$ Demikian juga dalam penelitian yang dilakukan oleh Parker, dkk (2014), didapatkan nilai $\mathrm{p}=0,02(\mathrm{p}<0,05)$, tingkat pendidikan memiliki pengaruh yang signifikan terhadap terjadinya persalinan preterm spontan. ${ }^{14}$ Grillo, dkk (2011) dalam studinya, pada subyek penelitian yang menempuh pendidikan selama $<9$ tahun dibanding yang pernah menempuh pendidikan $>9$ tahun lebih berisiko terjadi persalinan preterm, OR : 1,$58 ; 95 \% \mathrm{CI}, 1,09$ 2,30. Tingkat pendidikan merupa-kan salah satu indikator dari kondisi sosial ekonomi. ${ }^{13}$

\section{Pola kuman aerob urine pada kehamilan tanpa ancaman persalinan preterm}

Kehamilan merupakan salah satu faktor predisposisi terjadinya infeksi saluran kemih (ISK), dalam kondisi normal di dalam urine dapat ditemukan adanya bakteri, baik yang memberikan gejala (simptomatik) maupun tanpa gejala (asimptomatik). Persentase ditemukannya bakteri pada kehamilan normal tanpa gejala/bakteriuria asimptomatik di Amerika dilaporkan sebesar 2-7\%. Dalam beberapa penelitian, bakteriuria asimptomatik pada wanita hamil didapatkan golongan Enterobacteriaceae, yaitu Escherichia coli antara 60-90\%, selain itu juga dapat ditemukan Klebsiella, Pseudomonas, Enterobacter, Proteus.

Golongan coccus gram positif ditemukan Staphylococcus. Staphylococcus saprophyticus umumnya ditemukan pada kasus ISK wanita muda yang seksual aktif. Sebuah studi di Amerika Serikat tahun 2005 menyebutkan bahwa Escherichia coli merupakan kuman yang paling sering ditemukan pada kasus ISK asimptomatik, diikuti dengan Klebsiella pneumoniae, Staphylococcus dan Streptococcus. ${ }^{18}$ Ovalle, 2001, dalam penelitiannya menyebutkan bahwa $80-90 \%$ kuman Escherichia coli ditemukan pada wanita hamil dengan asimptomatik bakteriuria. ${ }^{19}$
Dalam sebuah penelitian yang dilakukan pada wanita hamil di Poli Hamil Rumah Sakit Dr. Soetomo, Surabaya tahun 2004 mengenai pola kuman dan tes kepekaan antibiotika wanita hamil, dari 376 wanita hamil tanpa gejala ISK yang dilakukan kultur urine porsi tengah, didapatkan 37 wanita hamil $(9,85 \%)$ dengan pertumbuhan kuman sebanyak $>10^{5} \mathrm{cfu} / \mathrm{ml}$, dengan jenis kuman terbanyak adalah Escherichia coli, yatu sebanyak 37,83\%, dan Staphylococcus aureus sebanyak $10,81 \% .^{15}$

Staphylococcus epidermidis dan Staphylococcus aureus merupakan mikroorganisme komensal atau flora normal pada kulit dan saluran urogenital, kuman ini terutama terkolonisasi pada axilla, vagina, faring, dan permukaan kulit lainnya. Dalam kondisi tidak normal, kuman ini berkaitan infeksi nosokomial di rumah sakit, terutama akibat dari pemasangan alat prostetik atau tindakan instrumentasi, misalnya pemasangan kateter atau implan pada pasien dengan kondisi imunosupresi. ${ }^{18}$

Pada penelitian ini dalam kelompok kehamilan tanpa ancaman persalinan preterm 55\% tidak didapatkan pertumbuhan bakteri. Dan dari biakan bakteri yang tumbuh adalah bakteri gram positif, Staphylococcus epidermidis dan Staphylococcus aureus masing-masing sebanyak 20\%. Serta 1 (5\%) bakteri gram negatif, Klebsiella pneumoniae. Hasil ini serupa dengan penelitian yang dilakukan oleh Suhatno dan Ikasari di RSUD dr. Soetomo, namun berbeda dibandingkan dengan hasil penelitian yang dilakukan di negara-negara barat. $^{28,29}$

Tabel 2. Hasil Identifikasi jenis bakteri

\begin{tabular}{lccc}
\hline Variabel & $\begin{array}{c}\text { PPI } \\
\mathrm{N}=20(\%)\end{array}$ & $\begin{array}{c}\text { Kontrol } \\
\mathrm{N}=20(\%)\end{array}$ & \multirow{2}{*}{$p^{*}$} \\
\hline Jenis Bakteri & & & \\
Staphylococcus epidermidis & $6(30,0)$ & $4(20,0)$ & 0,058 \\
Staphylococcus aureus & $3(15,0)$ & $4(20,0)$ & \\
Streptococcus viridans & $1(5,0)$ & $0(0,0)$ & \\
Streptococcus non hemolyticus & $1(5,0)$ & $0(0,0)$ & \\
Pseudomonas aeruginosa & $2(10,0)$ & $0(0,0)$ & \\
Klebsiella pneumoniae & $0(0,0)$ & $1(5,0)$ & \\
Escherichia coli & $3(15,0)$ & $0(0,0)$ & \\
Steril & $4(20,0)$ & $11(55,0)$ & \\
\hline *signifikan bila nilai $<<0,05$ & &
\end{tabular}

*signifikan bila nilai $\mathrm{p}<0,05$

Hal ini dapat disebabkan karena kontaminasi kuman saluran urogenitalia dalam spesimen pada saat pengumpulan sampel, mengingat Staphylococcus epidermidis dan Staphylococcus aureus adalah bakteri komensal yang sering ditemukan pada kulit dan saluran urogenital. Kebiasaan cebok dari arah depan ke belakang diduga dapat menyebabkan translokasi kuman komensal pada kulit vulva dibandingkan kuman dari saluran cerna, hal ini diduga dapat menyebabkan adanya 
perbedaan jenis kuman yang ditemukan pada kasus ISK dalam penelitian ini.

\section{Pola kuman aerob urine pada kehamilan dengan ancaman persalinan preterm}

Infeksi saluran kemih (ISK) merupakan salah satu faktor penyebab terjadinya ancaman persalinan preterm/ partus prematurus iminens (PPI). Dalam sebuah penelitian menyebutkan bahwa $39,6 \%$ persalinan preterm disebabkan oleh karena ISK. ${ }^{9}$ Schnarr \& Smaill (2008) menyebutkan bahwa etiologi ISK yang ditemukan pada wanita hamil paling sering adalah Escherichia coli (70-80\%). ${ }^{17}$ Dari beberapa hasil penelitian megenai hubungan antara ISK dengan PPI, antara lain Ovalle \& Levancini (2001), Jennifer (2012), menunjukkan hasil identifikasi kuman yang ditemukan secara umum adalah Escherichia coli. ${ }^{19,20}$

Escherichia coli dikenal sebagai kuman terbanyak sebagai penyebab ISK, kuman ini merupakan flora normal pada colon dan tidak berbahaya, tetapi pada kondisi tertentu kuman ini dapat menyebabkan infeksi oportunistik jika didapatkan pada organ lain, misalnya ISK bagian bawah hingga pyelonefritis, meningitis pada neonatus, hingga sepsis. Escherichia coli ini dapat menyebar melalui air yang terkontaminasi, terutama pada individu yang mengalami kondisi penurunan sistem imunitas. ${ }^{18}$

Ronald (2003) dalam artikelnya menyebutkan bahwa penyebab ISK tanpa komplikasi disebabkan oleh Escherichia coli (80\%), Staphylococcus saprophyticus (10-15\%), Klebsiella spp., dan Enterobacter. Patogenesis Escherichia coli uropatogen menyebabkan ISK dapat dijelaskan melalui mekanisme melekatnya pili atau fimbria Escherichia coli yang terkolonisasi di vagina dan saluran kemih pada epitel mukosa melepaskan senyawa adhesin untuk melekat pada mukosa buli, selain itu terdapat faktor lain yang menyumbang virulensi kuman ini adalah cytolysin dan aerobactin, cytolysin membunuh sel efektor dan menghambat fagositosis dan kemotaksis sel-sel lekosit. Aerobactin membantu kuman untuk mencerna zat besi yang kemudian digunakan untuk metabolisme sel kuman, sehingga Escherichia coli dapat mudah berreplikasi dan menembus mekanisme pertahanan dari tubuh inang, proses ini dapat berlangsung lebih cepat pada individu yang mengalami imunokompromi. ${ }^{18,21}$

Selain Escherichia coli dengan fimbriaenya sebagai kuman yang dominan sebagai penyebab ISK, Staphylococcus saprophyticus, Staphylococcus epider-midis dan Staphylococcus aureus sebagai kuman komensal juga diduga dapat menyebabkan ISK. Staphylococcus saprophyticus mempunyai kemampuan adhesi pada epitel saluran urogenital lebih kuat dibanding Staphylococcus epidermidis dan Staphylo-coccus aureus, tetapi semuanya mempunyai risiko yang sama dapat menyebabkan ISK. Staphylococcus melekat pada epitel saluran kemih melalui mekanisme yang berbeda dari Escherichia coli. Staphylococcus epidermidis berhubungan dengan kejadian ISK meskipun hanya ditemukan pada $20 \%$ kasus, sebagian besar kasus ISK yang disebabkan oleh Staphylococcus epidermidis asimptomatik. Populasi kejadian ISK karena Staphylococcus epidermidis terutama pada pasien yang menjalani rawat inap di rumah sakit. ${ }^{18}$

Dalam penelitian ini, pada kelompok kehamilan dengan ancaman persalinan preterm didapatkan beberapa kuman yang tumbuh, yaitu Staphylococcus epidermidis sebanyak 6 dari 20 sampel (30\%), Escherichia coli dan Staphylococcus aureus sebanyak 3 dari 20 sampel (15\%), Pseudomonas aeruginosa sebanyak 2 dari 20 sampel $(10 \%)$, dan $20 \%$ sampel tidak didapatkan pertumbuhan kuman. Hasil ini berbeda dengan beberapa literatur atau hasil penelitian-penelitian sebelumnya, kelemahan dari pengambilan sampel urine porsi tengah adalah adanya kontaminasi spesimen oleh kuman komensal/flora normal kulit sekitar genitalia, vulva dan vagina, terutama pada subyek obesitas dapat menyebabkan perbedaan jenis kuman yang ditemukan dalam penelitian ini. Kontaminasi urine dari kulit sekitar vulva atau vagina, mengingat Staphylococcus epidermidis adalah bakteri komensal yang sering ditemukan pada kulit dan saluran urogenital.

\section{Analisa mengenai perbedaan pola kuman aerob urine pada kehamilan dengan dan tanpa ancaman persalinan preterm}

Perbandingan antara jumlah koloni kuman dan identifikasi jenis kuman antara kelompok kontrol dan kelompok PPI, didapatkan nilai $\mathrm{p}$ masing-masing 0,063 dan $0,058(p<0,05)$, secara statistik baik jumlah koloni kuman dan jenis kuman tidak bermakna antara kedua kelompok. Walaupun secara statistik tidak bermakna, tetapi tampak perbedaan cukup jelas diantara kedua kelompok, dengan nilai $\mathrm{p}$ yang mendekati 0,05 dapat dikatakan bahwa perbedaan tersebut potensial bermakna. Didapatkan odd ratio sebesar 3,27 (CI 95\%: 0,80-13,35), disimpulkan bahwa dalam penelitian ini wanita hamil dengan jumlah koloni kuman urine $>10^{5}$ $\mathrm{cfu} / \mathrm{mL}$ memiliki risiko 3,27 kali lebih besar terjadi PPI dibanding wanita hamil dengan jumlah koloni $<10^{5}$ $\mathrm{cfu} / \mathrm{mL}$.

Persalinan preterm disebabkan oleh berbagai macam hal. ISK adalah salah satu dari beberapa faktor tersebut, penelitian ini tidak meneliti mengenai infeksi urogenital lainnya, misalnya bakterial vaginosis dan faktor bio- 
molekuler lainnya, misalnya mediator proinflamasi, selain itu salah satu kelemahan dari pengambilan sampel urine porsi tengah adalah adanya kontaminasi spesimen oleh kuman komensal/flora normal kulit sekitar genitalia, vulva dan vagina, terutama pada subyek obesitas, dari 6 subyek yang didapatkan kuman Staphylococcus epidermidis, 2 diantaranya overweight dan 1 obesitas gr. III, sehingga kemungkinan faktor tersebut dapat menyebabkan hasil penelitian ini secara statistik tidak bermakna.

Tabel 3. Hasil hitung jumlah koloni kuman

\begin{tabular}{|c|c|c|c|c|}
\hline Variabel & $\begin{array}{c}\text { PPI } \\
\mathrm{N}=20(\%)\end{array}$ & $\begin{array}{c}\text { Kontrol } \\
\mathrm{N}=20 \\
(\%)\end{array}$ & $p^{*}$ & $\begin{array}{l}\text { Odd ratio } \\
\text { (CI 95\%) }\end{array}$ \\
\hline \multicolumn{5}{|l|}{ Jumlah } \\
\hline \multicolumn{5}{|l|}{ Koloni } \\
\hline$<10^{5}$ & $11(55,0)$ & $16(80,0)$ & 0,063 & 3,27 \\
\hline$>10^{5}$ & $9(45,0)$ & $4(20,0)$ & & \\
\hline
\end{tabular}

* signifikan bila nilai $\mathrm{p}<0,05$

Menurut penelitian oleh Schieve dkk (1994), pada wanita dengan ISK, kultur urine didapatkan kuman $>10^{5}$ $\mathrm{cfu} / \mathrm{ml}$, risiko menjadi persalinan preterm dengan odd ratio sebesar 1,4 (CI 95\%; 1,3-1,6), bahkan pada kasus dengan pyelonefritis didapatkan odd ratio sebesar 2,6 (CI 95\%; 1,1-6,2). ${ }^{22}$ Demikian juga pada penelitian yang dilakukan oleh Feresu dkk (2004), pada wanita dengan ISK yang tidak mendapatkan terapi didapatkan odd ratio sebesar 2,85 (CI 95\%; 1,21-6,75), sedangkan pada wanita dengan ISK yang telah diberikan terapi didapatkan odd ratio sebesar 1,49 (CI 95\%; 0,95$2,35) .{ }^{23}$ Pada penelitian oleh Jain dkk (2013), kejadian persalinan preterm pada kehamilan dengan ISK yang tidak diterapi dibandingkan dengan kehamilan tanpa ISK didapatkan signifikan secara statistik, dengan nilai $\mathrm{p}=0,016(\mathrm{p}<0,05)$, dan odd ratio sebesar 3,27 (CI 95\%; $1,38-7,72){ }^{24}$

Tabel 4. Hasil koloni bakteri (bakteriuria)

\begin{tabular}{lccc}
\hline Variabel & $\begin{array}{c}\text { PPI } \\
\mathrm{N}=20(\%)\end{array}$ & $\begin{array}{c}\text { Kontrol } \\
\mathrm{N}=20(\%)\end{array}$ & $p^{*}$ \\
\hline Koloni Bakteri & & & \\
Bakteriuria $(-)$ & $4(20,0)$ & $11(55,0)$ & 0,048 \\
Bakteriuria $(+)$ & $16(80,0)$ & $9(45,0)$ & \\
\hline
\end{tabular}

*signifikan bila nilai $\mathrm{p}<0,05$

Didapatkan hasil yang signifikan antara kejadian bakteriuria dengan terjadinya PPI, dengan nilai $\mathrm{p}=0,048$ $(\mathrm{p}<0,05)$, sehingga dapat disimpulkan bahwa bakteriuria berapapun kepadatan kumannya berisiko menyebabkan terjadinya PPI pada wanita hamil. Sheiner dkk (2009) menyebutkan bahwa bakteriuria asimptomatik merupakan faktor risiko independen terhadap terjadinya PPI dan persalinan preterm, dalam studinya diperoleh nilai odd ratio sebesar 1,6 (CI 95\%: 1,5-1,7; p $<0,001) .{ }^{25}$ Kiran dkk (2010) dalam studinya mengenai nilai prediktif beberapa faktor risiko persalinan preterm didapatkan hubungan yang signifikan antara bakteriuria dengan terjadinya PPI, dengan nilai $\mathrm{p}=0,030(\mathrm{p}<0,05) .{ }^{26}$ Bakteriuria menyebabkan amnionitis dan memproduksi enzim kolagenase yang dapat merangsang terbentuknya prostaglandin dan selanjutnya dapat menginisiasi terjadinya persalinan. ${ }^{22}$

\section{SIMPULAN}

Pada kehamilan dengan ancaman persalinan preterm $80 \%$ didapatkan pertumbuhan kuman, dari kultur kuman yang ditemukan adalah Staphylococcus epidermidis (30\%) dan Escherichia coli (15\%). Jumlah koloni kuman aerob urine pada kehamilan dengan ancaman persalinan preterm lebih banyak dibandingkan dengan kehamilan tanpa ancaman persalinan preterm, tetapi secara statistik tidak berbeda bermakna. Risiko terjadinya PPI pada wanita hamil dengan jumlah koloni kuman urine $>10^{5} \mathrm{cfu} / \mathrm{mL} 3$ kali lebih besar dibanding wanita hamil dengan jumlah koloni $<10^{5} \mathrm{cfu} / \mathrm{mL}$. Jenis kuman aeroburine pada kehamilan dengan dan tanpa ancaman persalinan preterm hampir sama.

\section{DAFTAR PUSTAKA}

1. Goldenberg RL, Culhane JF, Iams JD and Romero R. Epidemiology and Causes of Preterm Birth. The Lancet. 2008;371:75-84.

2. Ananth CV and Vintzileos AM. Epidemiology of Preterm Birth and its Clinical Subtypes. The Journal of Maternal-Fetal and Neonatal Medicine. 2006;19(12):773-82.

3. Sea Orchid. Use of Evidence Based Practices in Pregnancy and Childbirth: South East Asia Optimising Reproductive and Child Health in Developing Countries Project. Plos One. 2008;3(7):2646.

4. RISKESDAS. Kesehatan Reproduksi. Dalam: Riset Kesehatan Dasar. Jakarta: Badan Penelitian dan Pengembangan Kesehatan Kementrian Kesehatan RI. 2013. h. 202.

5. Clements KM, Barfield WD, Ayadi MF and Wilber N. Preterm Birth-Associated Cost of Early Intervention Services: An Analysis by Gestational Age. Pediatrics. 2007;119(4):866-74.

6. Russell RB, et al. Cost of Hospitalization for Preterm and Low Birth Weight Infants in the United States. Pediatrics. 2007;120(1):1-9.

7. Cram LF, Zapata MI, Toy EC and Baker B. Genitourinary Infections and Their Association 
with Preterm Labor. American Family Physician. 2002;65(2):241-8.

8. Cunningham GF, et al. Preterm Birth. Dalam: Cunningham GF, et al. penyunt. Williams Obstetric. New York: Mc Graw Hill Medical; 2010. p. 804-31.

9. Dimetry SR, et al. Urinary Tract Infection and Adverse Outcome of Pregnancy. J Egypt Public Health Assoc. 2007;82(3,4):203-18.

10. Nabavizadeh SH, et al. Retrospective Study of Factors Related to Preterm Labor in Yasuj, Iran. Int J. of Gen. Med. 2012:1013-7.

11. Dekker GA, et al. Risk Factors for Preterm Birth in an International Prospective Cohort of Nulliparous Women. Plos One. 2012;7(7):39154.

12. Begum F, Buckshe K and Pande J. Risk Factors Associated with Preterm Labor. Bangladesh Med. Res. Counc. Bull. 2003;29(2):59-66.

13. Grillo E and Freitas PF. Smoking and Other Pregestational Risk Factors for Spontaneous Preterm Birth. Rev. Bras. Saúde Matern. Infant. 2011; 11(4):397-403.

14. Kozuki N, et al. The Associations of Parity and Maternal Age with Small-for-Gestational-Age, Preterm, and Neonatal and Infant Mortality: a Meta-Analysis. BMC Public Health. 2013:52.

15. Kalalo LP, Aryati and Subagjo B. Pola Bakteri dan Tes Kepekaan Antibiotika wanita Hamil dengan Bakteriuria Asimptomatis. Indonesian Journal of Clinical Pathology and Medical Laboratory. 2006;12(3):103-9.

16. Nicolle LE, et al. Infectious Diseases Society of America Guidelines for the Diagnosis and Treatment of Asymptomatic Bacteriuria in Adults. Clin. Inf. Dis. 2005;40(6):43-54.

17. Smaill F. Asymptomatic Bacteriuria in Pregnancy. Best Practices and Research Clinical Obstetrics and Gynecology. 2007;21(3):439-50.

18. Mahon CR, Lehman DC and Manuselis G. Enterobacteriaceae. Dalam: Textbook of Diagnostic Microbiology. Missouri: Saunders; 2011. p.427-61.
19. Ovalle A and Levancini M. Urinary Tract Infections in Pregnancy. Current Opinion in Urology. 2001;11:55-9.

20. Jennifer $P$, et al. Asymptomatic Bacteriuria in Pregnancy: Prevalence, Risk Factors and Causative Organisms. Sri Lankan Journal of Infectious Diseases. 2012;1(2):42-6.

21. Ronald A. The Etiology of Urinary Tract Infection: Traditional and Emerging Pathogens. Dis. Mon. 2003;49:71-82.

22. Schieve AL, et al. Urinary Tract Infection during Pregnancy: Its Association with Maternal Morbidity and Perinatal Outcome. Am. J. of Pub H. 1994;84(3):405-10.

23. Feresu S, Harlow SD and Woelk GB. Risk factors for prematurity at Harare Maternity Hospital, Zimbabwe. International Journal of Epidemiology. 2004;33:1194-201.

24. Jain V, Das V, Agarwal A and Pandey A. Asymptomatic Bacteriuria \& Obstetric Outcome Following Treatment in Early Versus Late Pregnancy in North Indian Women. Indian J Med Res. 2013:753-8.

25. Sheiner E, Mazor DE and Levy A. Asymptomatic Bacteriuria During Pregnancy. J Maternfetal Neonatal Med. 2009;22(5):423-7.

26. Kiran P, Ajay B, Neena $G$ and Geetanjaly K. Predictive Value of Various Risk Factors for Preterm Labor. J Obstet Gynecol India. 2010; 60(2):141-5.

27. Wilson ML and Gaido L. Laboratory Diagnosis of Urinary Tract Infection in Adults Patients. Medical Microbiology. 2004:1150-8.

28. Ikasari KD, Sulistyono A and Debora K. Gambaran Mikroorganisme Vagina pada Kehamilan Normal dan Kehamilan Dengan Ketuban Pecah Dini. Penelitian Program Pendidikan Dokter Spesialis Obstetri \& Ginekologi RS dr. Soetomo. 2015.

29. Suhatno dan Subagyo B. Bakteriuria Asimtomatik pada Kehamilan. Penelitian Program Pendidikan Dokter Spesialis Obstetri \& Ginekologi RS dr. Soetomo. 1975. 